\title{
Resilience of small-scale societies: a view from drylands
}

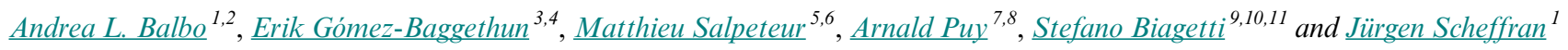

\begin{abstract}
To gain insights on long-term social-ecological resilience, we examined adaptive responses of small-scale societies to dryland-related hazards in different regions and chronological periods, spanning from the mid-Holocene to the present. Based on evidence from Africa (Sahara and Sahel), Asia (south margin of the Thar desert), and Europe (South Spain), we discuss key traits and coping practices of small-scale societies that are potentially relevant for building resilience. The selected case studies illustrate four main coping mechanisms: mobility and migration, storage, commoning, and collective action driven by religious beliefs. Ultimately, the study of resilience in the context of drylands emphasizes the importance of adaptive traits and practices that are distinctive of small-scale societies: a strong social-ecological coupling, a solid body of traditional ecological knowledge, and a high degree of internal cohesion and self-organization.
\end{abstract}

Key Words: adaptation; climate change; coping mechanisms; drylands; resilience; social-ecological systems; sustainability; traditional ecological knowledge

\section{INTRODUCTION}

A growing body of literature suggests that the possibility of a major irreversible state shift in the Earth's biosphere, partially driven by human pressure on the environment, can no longer be excluded (Rockström et al. 2009, Barnosky et al. 2012). With increased frequency and intensity of disturbances brought about with climate change, our exposure to risks from climate-related hazards seems to have become unavoidable, and so is the need for responses to mitigate its likely negative impacts (Barnett and O’Neill 2010). Climatic models that predict temperature extremes and drought intensification in the current century suggest that these considerations are paramount in drylands (IPCC 2012). In addition, drylands contain human populations with the highest growth rates (35\% of global population to date) despite having the lowest biological productivity on Earth (Stafford Smith et al. 2009), thus offering the perfect settings for extreme vulnerability to climate-related hazards (Adger et al. 2012).

In spite of the challenges for human settlement in drylands, archaeological and historical research has revealed long-term trajectories of human-environment interaction in these regions. This long-term coevolution has generated social-ecological systems where people have developed specific coping strategies and institutions that are adapted to recurrent environmental stress (Berkes et al. 2000, Folke et al. 2002, Gómez-Baggethun et al. 2012). As a result, climatic events that are considered extreme elsewhere may be perceived as a systemic element of environmental variability in regions that have traditionally been exposed to them (Colding et al. 2002, Hoffman and Oliver-Smith 2002, Gómez-Baggethun et al. 2013a). On this line of thought, a number of researchers have highlighted that hazards are socially mediated. That is, people and communities can be considered as constituent parts of hazards, and hazards can be considered as constituent parts of social-ecological systems (Torry et al. 1979, Oliver-Smith 1999, Colding et al. 2002, Haque and Etkin 2007).
As a consequence, the study of the long-term ability of socialecological systems to mitigate, adapt to, or aggravate the effects of environmental hazards has crucial implications for the management of present-day resources and climate-related issues worldwide (McIntosh et al. 2000).

Climate-related hazards are often described in terms of frequency and intensity (IPCC 2012). In drylands, perhaps more than elsewhere, the frequency and intensity of climate-related hazards strongly contribute to determine the vulnerability of local socialecological systems. Climatic and environmental change in drylands is characterized by high variability over the short-term, implying high diurnal and seasonal variations, as well as climatic unpredictability over annual and decadal periods (Balbo et al. 2014). Any annual deviation in precipitation from the mean in drylands may potentially lead to droughts, fires, floods, or frosts, affecting land productivity (e.g. soil salinization and crusting, loss of vegetation cover and biomass, runoff and erosion), habitability, and consequently food, energy, and water security. The high variability characterizing dry climates implies higher probabilities of occurrence of extreme conditions and increased uncertainty in the evaluation of available resources (McGlade 2014).

In this paper we examine case studies from different dryland regions and chronological periods to discuss the potential contribution of small-scale society studies for evaluation and building of resilience. Small-scale societies have been defined as past or present societies living at low population densities in small groups ranging from a few dozen to a few thousand people, subsisting by hunting-gathering or by farming or herding (Diamond 2012). For the purpose of this work, we further characterized small-scale societies as those human groups integrated in social-ecological systems characterized by feedback mechanisms of low complexity, where the effects of a given strategy are predominantly local and last for short periods of time, i.e., days to years. This definition intentionally excludes the

\footnotetext{
${ }^{1}$ Research Group Climate Change and Security (CLISEC), Institute of Geography, Center for Earth System Research and Sustainability (CEN), University of Hamburg, ${ }^{2}$ Complexity and Socio-Ecological dynamics (CaSEs), Institució Milà i Fontanals, Spanish National Research Council (IMF-CSIC), ${ }^{3}$ Department of International Environment and Development Studies, Norwegian University of Life Sciences (NMBU), ${ }^{4}$ Norwegian Institute for Nature Research (NINA), ${ }^{5}$ Institut de Ciència i Tecnologia Ambientals, Universitat Autonoma de Barcelona (ICTA-UAB), Edifici C Campus de la UAB, ${ }^{6}$ ERAAUB, Dept Prehistòria, Història Antiga i Arqueologia, Universitat de Barcelona, ${ }^{7}$ Institute of Geography, University of Cologne, ${ }^{8}$ Maritime Civilizations Department, Recanati Institute for Maritime Studies, University of Haifa, ${ }^{9}$ Complexity and Socio-Ecological dynamics (CaSEs), Spain, ${ }^{10}$ Departament d'Humanitats, Universitat Pompeu Fabra, ${ }^{11}$ School of Geography, Archaeology and Environmental Studies (GAES), University of the Witwatersrand
} 
potential cumulative effects of actions by aggregates of smallscale societies. Adapting the frameworks proposed by Agrawal et al. (2008) and Thornton and Manasfi (2010), we discuss (1) mobility and migration, (2) commoning, (3) storage, and (4) collective action driven by shared religious beliefs as coping mechanisms that play a central role in ensuring the viability of small-scale social-ecological systems in arid environments. Our reference case studies are drawn from archaeological, historical, and anthropological research, and include Sahelian and Sahara pastoralists, irrigated fields of Andalusi origin (Iberian Peninsula), hunter-gatherers and agro-pastoral groups of Gujarat, India, and traditional farmers of Doñana, Southwest Spain. Although some of the adaptive strategies discussed are found in more than one case study, in the following sections we pair each social-ecological system with a coping mechanism that illustrates a significant aspect of its resilience capability in the face of particular climate-related disturbances. Our final aim is to assess the added value of integrating social and environmental information from small-scale societies in a long-term perspective to inform action aimed at mitigating the impact of climate-related hazards and preventing disaster.

\section{CASE STUDIES}

\section{Migration and mobility: the case of Saharan and Sahelian pastoralists}

Mobility and migration are core adaptive strategies within dryland pastoral systems in response to unpredictable and irregularly distributed resource availability, as well as to cope with frequent social, political, and economic change over broad and sparsely settled regions (Kavoori 1996, Salpeteur et al., in press). The viability of mobility and migration strategies over the long term is in turn related to the existence of (1) organizations and institutions internally regulating the mobile way of life, such as the distribution of functions among members of coexisting migration groups (Agrawal 2003); (2) formal and informal mechanisms or institutions to manage interactions with external resource users and owners, enabling negotiation and conflict resolution (Nori et al. 2008, Hussein 1998); and (3) higher institutional settings that frame land tenure and movement patterns across large areas (Galvin 2009, Nori and Davies 2007, Robinson and Berkes 2010, Oteros-Rozas et al. 2013).

Sahelian droughts have been described as some of the largest ongoing climate changes (Bates et al. 2008). Here, mobility has been the most common strategy to cope with climatic variability by spreading risk across space and time, with migration and pastoralism being widely adopted for centuries (McCarthy et al. 2000, FAO 2001, Galvin 2009, Dong et al. 2011). In the Central Sahara, animal husbandry has been the most important strategy for food security since the emergence of domesticated animals in the region circa $9 \mathrm{ka}$ BP (thousands of years before present; Marshall 2000, Gifford-Gonzalez and Hanotte 2011). Here, pastoralism was never fully replaced by agriculture, owing among other things to the gradual intensification of aridity starting locally circa $4 \mathrm{ka}$ BP (Di Lernia and Merighi 2006). Even during the Garamantian kingdom (c. 700 BC to 1000 AD), the earliest attested Saharan state, and later during the Islamic period (c. 700-1600 AD), the cultivation of crops in the oases was largely integrated with pastoralism in the mountain ranges (Wilson 2012, Mattingly and Sterry 2013, Mori 2013). In the same region, the
Kel Tadrart Tuaregs of the Acacus Mountains (Southwest Libya) offer a contemporary example of multiresource pastoralism (Biagetti 2014). Over the past century, increasingly affected by dry spells and political restrictions to mobility and resource access, Saharan and Sahelian pastoral groups have significantly broadened the type of labor activities in which they are involved in rural as well as urban areas.

A growing body of literature aims at understanding migration as a coping mechanism (Afifi and Jäger 2010, Piguet et al. 2011), and in an historical long-term perspective, migration appears as a response in climate adaptation (Scheffran et al. 2012a). When migrations take place, existing social networks appear to work as potential security nets (Scheffran et al. 2012a, b). Through such networks, family members are sent away to diversify income, gain knowledge, spread risk, reduce population pressure, insure against future shocks and stresses, and gather capabilities to sustain the community. Although outmigration has been identified elsewhere as a major driver for the loss of local ecological knowledge (Iniesta-Arandia et al. 2015), in other cases migrant social networks show potential for the increase of social resilience in vulnerable communities, by offering new opportunities to diversify household livelihoods and triggering innovations across regions through, e.g., remittance flows, transfer of knowledge, technological transfer and renewable energy, collaborative projects for water management, and education to cite but a few (Scheffran et al 2012b, Ngaruiya et al. 2015).

\section{Commoning: the case of Andalusi agriculturalists}

Irrigated social-ecological systems of Andalusi origin (711-1492 AD) encompass long-lasting intensive agricultural systems that have shown a high degree of resilience to different social and climatic disturbances over the centuries (Puy and Balbo 2013, Puy et al. 2016). They were implemented in the Iberian Peninsula after the arrival of Arab and Berber tribes and clans in $711 \mathrm{AD}$ (Guichard 1976, Barceló 1986), and allowed to acclimatize for the first time in the western Mediterranean oriental crops such as the orange or the lemon tree, the artichoke, the cucumber, the watermelon, and the sugar cane (Watson 1983, Retamero 1998). The original Andalusi irrigated field systems extended over limited areas of 2 ha or less (Sitjes 2006). These were largely extended after the feudal conquest of al-Andalus, made in the context of the European Crusades (Torró 2007, Kirchner 2009, Guinot and Esquilache 2012). Through history, irrigated fields of Andalusi origin have shifted from subsistence-based to stateregulated and market-oriented production, and some of them are currently cultivated for the production of fruits and vegetables that are exported across Europe.

Transformations and enlargements of traditional hydraulic systems are constrained by water availability and favorable slopes, because gravity is needed to allow water flow across the channel network (Barceló 1989). In addition, the initial channel layout and the location of hydraulic devices and irrigated plots cannot be modified during later extensions without putting the whole system at risk (Barceló 1989, Glick 1990). In spite of these limits to growth, traditional hydraulic systems might involve flexible water allocation regimes, which can be changed to effectively cope with water shortages. In that sense, the long-term resilience of hydraulic systems largely depends on their governance with 
institutional arrangements able to swiftly respond to dry spells and to solve conflicts between irrigators potentially arising in times of water shortages. Fines to irrigators caught stealing water may be reinforced during the dry season as a deterrent to free riding and to prevent situations potentially leading to the "tragedy of the commons" (Hardin 1968, Ostrom 1990). Water allocation rules may be temporarily modified to minimize the loss in bulk production, e.g., by giving irrigation priority to crops that are in most need of water (Maas and Anderson 1978), by promoting a temporary reduction in irrigated land (Pérez et al. 2011), or by maximizing the net income per unit of water used rather than per land unit (Fereres and Soriano 2007). Adaptive water allocation rules and conflict-solving mechanisms governed by local institutions and communities are critical in ensuring the viability of these intensive agrarian areas over the long-term. The Council of the Wise Men of Murcia or the Water Tribunal of València are examples of such institutions, dating back to al-Andalus and included in the UNESCO's list of intangible heritage since 2009.

Many authors have characterized small-scale hydraulic systems as better endowed to achieve long-term survival in the face of uncertainty (Guijt and Thompson 1994, Mabry 1996a, b, Ertsen et al. 2013). However, recent studies suggest that increased water shortage, sprawling cities, market competition, aging of cultivators, and lack of modernization could undermine in the short- to mid-term the resilience of both small- and large-scale traditional Mediterranean irrigated fields (Rodríguez Díaz et al. 2007, Martínez-Fernández et al. 2013, Iniesta-Arandia et al. 2015). New institutional challenges arise as agricultural production becomes economically less important for the local population, often employed elsewhere. Work in the field has become a weekend diversion for many, and cycling, trekking, and historical routes across the irrigated fields are becoming an increasingly relevant source of income. This new wave of lucrative and ludic activities should be coupled with institutional designs aimed at maintaining traditional hydraulic systems attractive, viable, and resilient. Awareness of potential drawbacks prompted by dependency on external inputs should contribute to promoting the sustainable use of amenities and ecosystem services in these areas.

\section{Storage: the case of early agro-pastoral systems in Gujarat}

Available evidence from Gujarat (Northwest India) suggests that Holocene hunter-gatherer populations settled the region circa 9 ka BP. In contrast with more common situations where huntergatherers were rapidly replaced by agro-pastoral groups (e.g., Neolithic Europe; see Fort et al. 2012), hunter-gatherers in Gujarat interacted with agro-pastoral populations for millennia (c. 7.5-4 ka BP) before disappearing circa 4 ka BP. Agent-based models developed for Gujarat suggest, on one hand, that huntergatherer resource procurement strategies were highly adapted to the local climate, at least until drought frequency intensified around circa $4 \mathrm{ka} \mathrm{BP}$ (Clift and Plumb 2008, Anderson et al. 2010, Balbo et al. 2015). On the other hand, the same agent-based models suggest that the viability of the earliest agro-pastoral populations of Gujarat depended largely on consistent storage of foodstuff and on livestock, jointly covering at least $40 \%$ of their caloric intake. Absent from hunter-gatherer archaeological contexts, evidence of substantial storage features and cattle domestication becomes ubiquitous in agro-pastoral contexts from the late phases of the Holocene (Patel 2009, Balbo et al
2015). Storage, livestock being a variance of it (O'Brien and Bentley 2015), was interpreted as the key strategy that allowed agro-pastoral groups in Gujarat to overcome the period of intensified drought responsible for the disappearance of huntergatherer populations in the region circa $4 \mathrm{ka} \mathrm{BP}$.

The case of Gujarat indicates that short-term climatic variation (standard deviation) is more relevant than long-term change (mean) in shaping population dynamics in drought-prone regions (Balbo et al. 2014). In such areas, unlike regions characterized by a steady climate ensuring year-round yields, delayed food consumption becomes fundamental to lower vulnerability and increase resilience. In the context of small-scale societies and early agricultural systems, the boundary between subsistence storage and surplus storage has been assessed to be the amount of foodstuff needed to cover three consecutive years with scarce harvests (Angourakis et al. 2015). Past those limits, storage can no longer be considered as a mere risk-reduction strategy, but rather a wealth-accumulation strategy, as emerging from the study of the evolution of Neolithic food storage in the Near East and in Europe (Kuijt 2015, O'Brien and Bentley 2015, Winterhalder et al. 2015). In such contexts, the production of surplus is in most cases directly related to the existence of effective storage structures and capabilities (Balbo et al. 2015).

Beyond the context of Gujarat, storage has emerged as a key buffering strategy to face fluctuating crop production from the very early stages of agriculture development in other regions of the world, because it allows the delayed consumption of foodstuff in sedentary agricultural societies (Balbo 2015). This adaptive strategy was intertwined with domestication in drylands in Southwest Asia (Near East) in the early Holocene, where storage of wild cereal grains is attested in Dhra' as early as $11 \mathrm{ka} \mathrm{BP}$ (Kuijt and Finlayson 2009, Kuijt 2015). In fact, agent-based models suggest that the agricultural lifestyle all together would hardly have been viable without the development of consistent and systematic storage practices and technologies (Angourakis et al. 2015). Finally, as production and storage capabilities increased above subsistence needs, the accumulation of surplus may have contributed in some measure to some of the major challenges inherited by contemporary societies, predominantly characterized by market-oriented farming: (1) the exponential spread of agricultural systems and related environmental transformations; (2) the transition to less cohesive societies, prompted in part by the accumulation of surplus (De Saulieu and Testart 2015); and (3) the progressive decoupling, in terms of perceived dependency between agricultural production and climate variability.

\section{Shared belief systems: the case of farmers in Doñana, Southwest} Spain

Doñana, a system of wetlands and sand dunes located in Southwest Spain, provides an example of climate-related collective action based on shared belief systems (López-Taillefert 1998). The area's climate has been described as semiarid (Romero Macías et al. 1996), and high precipitation irregularity leading to significant aridification phases has characterized the area in given historical periods (Sousa and García-Murillo 2003, GarcíaBarrón et al. 2011). Consistently settled since the Phoenician and Roman periods, the marshlands of Doñana have been characterized by a subsistence-oriented economy, where in the absence of modern mechanization in agriculture until the mid 
20th century livelihood relied heavily on traditional knowledge and practices (Gómez-Baggethun et al. 2010). Livestock raising and slash and burn shifting agriculture (to deal with lack of nutrients) were the main subsistence practices in use. Large parts of Doñana territory were managed as commons until land privatization in the mid 19th century (Ojeda 1987), and conservation enclosures in the mid 20th century brought about major restrictions for locals in access to land and resources (Gómez-Baggethun et al. 2013a). Farmers of Doñana gradually developed a rich diversity of coping strategies to spread climaterelated risk across space, i.e., mobility; time, i.e., storage and rationing; assets, i.e., diversification; and households or communities, i.e., sharing and pooling (Giansante et al. 2003, Sauri et al. 2003, Gómez-Baggethun and Reyes-García 2013). In case of extreme events such as prolonged droughts, such coping strategies were complemented with collective action practices and rituals based on a shared system of beliefs around the local religious icon Virgen del Rocío (Our Lady of the Dew; Christian 1982, Barriendos 2005). The Virgin has been venerated by the locals since $1280 \mathrm{AD}$ for her believed power to protect from environmental calamities (Flores Cala 2005), and at least since the 16th century locals have organized religious ceremonies, known as Venidas de la Virgen, to pray for her assistance in response to climate extremes (Flores Cala 2005).

The preservation of local historical archives informs on the occurrence of prolonged droughts that brought about crop failure and the dying of people and cattle (Flores Cala 2005). In Doñana, the occurrence of exceptional climate-related events matches with the celebration of ceremonies starring the statue of the Virgen del Rocío for the period 1582-1930 AD (Gómez-Baggethun et al. 2012). Most ceremonies were performed in spring to "prevent" the occurrence of a dry year. Requests to celebrate the ceremony were made by the guilds to the village council and then commanded to religious authorities, which had the final word on the possibility to perform them. By maintaining and strengthening a common identification within the framework of a shared belief system, such rituals contributed to keeping cohesion in the community during periods of shortages, arguably limiting the emergence of conflicting behavior such as robberies. The shared system of local beliefs played a critical role in maintaining long-term social-ecological resilience by facilitating collective responses and by preventing social unrest.

In addition to providing an expectation of relief, religious processions had associated effects that may also have contributed to building resilience. For example, during processions, local authorities provided food to the porters of the statue, recruited among the poorest members of the community, thus contributing to alleviating food shortage among the most exposed. Furthermore, generous public expenditure for the ceremonial processions, including the repair of local tracks, could serve as stimulus to the local economy (Flores Cala 2005). Belief-based behavior prompts changes in other behavioral spheres, e.g., affecting social structure by promoting cooperation and collective action. In spite of their potentially conservative and inhibitory nature, belief systems and religious entities can thus, in specific cases, act as a sort of mitigation technology enhancing social cohesion (Gómez-Baggethun et al. 2012). From a more general viewpoint, belief-based behavior is part of a broader framework made of traditional ecological knowledge (TEK).

\section{PILLARS OF RESILIENCE IN SMALL-SCALE SOCIETIES}

Population thresholds, mostly ranging from a few hundred to a few thousand, have often been used to define small-scale societies (Smith and Wishnie 2000, Diamond 2012). In this paper, rather than considering size as a set parameter critical to conceptualize small-scale societies, we see it as an emerging feature defined by the social-ecological contexts in which small-scale societies develop through time their resilience strategies and climaterelated coping mechanisms. This approach highlights the dynamic nature of small-scale societies and stresses the need to focus on their adaptive traits and practices, which ultimately depend on their environmental awareness and institutional flexibility. Environmental awareness relies on the maintenance of strong social-ecological coupling and on the continuation of a solid body of TEK. Institutional flexibility, with the capacity for collective responses, depends on the preservation of internal cohesion and on the conservation of a high degree of self-organization (Agrawal et al. 2008, Reyes-Garcia et al. 2013). These adaptive traits are found across the case studies presented above and have been fundamental to enhance the resilience of small-scale societies in the face of climatic change, in drylands and beyond.

Regarding environmental awareness, people tend to pay attention to issues that are spatially, temporally, and socially close to their daily experiences, thus being within their own window of attention (Scheffran 2011). Small-scale societies, including those found in drylands, are often located in rural contexts with frequent exposure to, and high dependency on, local food-production processes and related activities. As a result, members of smallscale societies have often developed robust social-ecological bonds and have a more marked temporal, spatial, and social proximity with issues related to climate change (IPCC 2012), which define the perception of and response to external stressors (Pyhälä et al. 2016). Specifically, being consistently exposed to climate variability and extremes, small-scale societies in drylands have maintained a strong sense of environmental awareness that enables them to make an informed evaluation of the potential effects of local temperature rise, related hazards, and possible responses, e.g., concerning food production systems (Wildcat 2013). Although having significantly different group sizes, all social-ecological systems (foraging, pastoral, agricultural, and mixed) reviewed in this paper showed a high degree of investment in coping mechanisms aimed at the management of local food resources, the availability of which has been historically strongly coupled with climate variability, at least until the introduction of mechanization and modern technologies. Migration, storage, regulated sharing of common pool resources, and shared belief systems have all played important roles as buffering strategies aiming at dealing with shortages and preventing social conflict in times of scarcity, thus ensuring the continuity of the basic structure and function of the social-ecological system in which they are implemented, that is, their resilience.

The effectiveness of such coping strategies relies largely on a solid body of TEK. TEK refers to a cumulative assemblage of knowledge, practice, and belief, evolving by adaptive processes and handed down through generations by cultural transmission, about the relation of living beings, including humans, with one another and with their environment (Berkes et al. 2000). Within small-scale societies, TEK forms an ensemble of intangible 
customary devices that include multiple practices to cope with disturbance and change (Gómez-Baggethun et al. 2013b). As such, TEK includes adaptive strategies in response to environmental hazards that are based on long-term trajectories of human-environment interaction. The ways in which TEK is acquired, shared, and maintained within a given group, as well as between groups, depend largely on the social-ecological context in which the group is embedded, and may as such involve communities of different sizes or distinctive sectors within a given community. For example, knowledge about migration routes and related resources among pastoral groups are often shared within migration clusters based on kinship, as is the case for present-day Rabari pastoral groups in Gujarat (Salpeteur et al. 2015). Likewise, storage facilities in early farming communities may have been implemented differently at the individual, household, subgroup, and group level, depending on the group social structure and on the TEK held by those implementing them (Balbo et al. 2014). Irrigators from different hydraulic systems may share basic knowledge regarding irrigation, but their water allocation regimes and adaptive solutions to uncertainty will be specifically adapted to local social-ecological conditions. Likewise, as seen in the case of farming populations in Doñana, a specific aspect of TEK, i.e., that concerning belief-based behavior, tends to be shared among larger portions of a given community or larger communities altogether (Gómez-Baggethun et al. 2012).

The constitution, implementation, and maintenance of TEKbased actions are largely based on group cohesion. Anthropological and historical studies have widely documented the existence of group-size thresholds, within a given decisionmaking process and the involved community, beyond which collaboration, agreement, and flow of information are seriously impaired (overview in Alberti 2014). This matter had previously been described as the "scalar stress" issue (Johnson 1982), in which the increase in population is correlated with an increase in in-group disputes. Rising communication flows caused by booming populations tend to reach a threshold beyond which the workload required to process the information exceeds the intellectual capacity of the group members or the amount of resources they want to spend in coordination, leading to disappointment, stress, and conflict (Meier 1972). Different thresholds ranging from 6 to 200 individuals have been proposed for the onset of unmanageable disputes leading to group division, development of hierarchical structures, and/or collapse (Johnson 1982, review in Alberti 2014). Although critical thresholds may vary depending on pre-existing social and ecological factors, an early example being that of storage among Neolithic agriculturalists, the very existence of a negative correlation between cooperation, agreements, and group size suggests that (1) the emergence and maintenance of swift collective and coordinated action may have been easier in relatively small populations, contributing, e.g., to the long-term viable management of such commons as water, pasture, or foodstuff (Ostrom 1990); and (2) the existence of a strong internal cohesion in small-scale societies has contributed to improving their capacity to adapt and rearrange their strategies in the face of climatic disturbances, providing they were able to maintain a highdegree of self-organization (Adger 2003, Pelling and High 2005).

Together with internal cohesion, autonomy and self-organization are critical attributes endowing small-scale societies with the capacity to develop dynamic coping mechanisms in a timely way. Self-organization is observed across small-scale societies of different types and sizes. Highly mobile pastoral and foraging groups are topic examples of self-organized communities, living across established administrative and political borders (Agrawal 2003). Autonomous communities have implemented irrigated agricultural systems of Andalusi origin mostly as self-organized systems. Although these social-ecological systems are now embedded in broader political and economical frameworks, such as the hydrographical confederations defining the management and distribution of water proceeding from major Iberian river systems, local communities retain a relatively large degree of autonomy for regulating water allocation among local users (Ostrom 1990). The capacity for self-organization may therefore enable small-scale societies to persist in spite of external political changes or economical shifts and to respond faster than largerscale governance bodies to local climatic challenges because of their accurate social-ecological knowledge and greater operational proximity.

Two questions remain. First, how can semiautarchic systems, characterized by strong internal cohesion and self-organization, be integrated in the contemporary context of global interconnectedness? Second, to what the degree can their traditional knowledge and coping practices be applied today? Accelerated global change may rapidly push slowly built coping competence in different directions, thus affecting the capacity of small-scale societies, in drylands as elsewhere, to respond to climate-related stress. Some features identified as historically nurturing community resilience to cope with environmental change, such as social-ecological coupling and living bodies of TEK, are likely to be eroded as small-scale societies become increasingly integrated in the market economy (GómezBaggethun et al. 2010, Reyes-Garcia et al. 2013). The recent acceleration in urbanization and technification is also likely to foster social-ecological decoupling, promoted by the fast deterioration of generalized ecological knowledge and the physical and cognitive detachment of humans from the environment. On the other hand, contemporary hyperconnectivity, with increased and generalized access to long-range transportation and communication, promotes migratory activity and the intensification of exchanges. With migration routes and communication networks, goods, information, and knowledge travel faster over larger areas (see Sow et al. 2015, for the case of Morocco). These new dynamics, coupled with sensible regulations, have the potential to increase the flexibility, diversity, and creativity of communities in addressing environmental stress, fostering the development of innovative coping practices (Scheffran et al. 2012b) and the integration of TEK with new technologies for resilience and sustainability solutions (Berkes et al. 2000, Kristofferson and Berkes 2005, Berkes and Turner 2006, Armitage et al. 2009).

\section{CONCLUSIONS}

Small-scale societies in drylands are characterized by their exceptional exposure to climate-related hazards. For that reason, the long-term study of foraging, pastoral, and farming socialecological systems in drylands provides a vantage viewpoint into the challenges and opportunities for resilience under current global climatic trends. 
A long-term perspective on climatic adaptive capacity among small-scale societies in drylands highlights key adaptive traits that have been relevant for the maintenance of environmental awareness and institutional flexibility, with potential for fostering resilience strategies in regions exposed to climate-related hazards: maintenance of strong social-ecological coupling, living bodies of TEK, preservation of internal cohesion, and conservation of a high-degree of self-organization.

However, coping mechanisms to build resilience that have been implemented and successfully used over the long term are now facing new challenges as small-scale societies become globally integrated. As social complexity increases, supported by technological and institutional innovation, biophysical constraints on small-scale societies are released, leading to a gradual decoupling of social-ecological systems (Mumford 1934, Hill et al. 2015). The progressive assimilation of small-scale societies within the global work market poses significant challenges for the integration of TEK systems in the spheres of formal education and new technologies (Kramer 2005). Culturally and geographically consistent in traditional smallscale societies, identity and group cohesion are increasingly layered and distributed concepts in present hyperconnected societies. Finally, adaptive flexibility arising from selforganization in small-scale societies may be hampered when they become embedded within broader institutions and organizations that oversee or fail to involve local and informal organizations and institutions (Holling and Meffe 1996, Gómez-Baggethun et al. $2013 a$ ).

Responses to this article can be read online at: http://www.ecologyandsociety.org/issues/responses. $\mathrm{php} / 8327$

\section{Acknowledgments:}

We would like to thank Victoria Reyes-García and Marco Madella for involving us in the workshop "Small-Scale Societies and Environmental Transformations: Co-evolutionary Dynamics" sponsored by the Catalan Institution for Research and Advanced Studies (ICREA). We much appreciate the contribution of two anonymous reviewers. AB worked on this paper on a Juan de la Cierva contract from the Spanish Ministry of Economy and Competitiveness (MINECO) and on a Humboldt Research Fellowship from the Alexander von Humboldt Foundation. AP worked on this paper on a Humboldt Research Fellowship from the Alexander von Humboldt Foundation and on a Marie Curie IntraEuropean Fellowship from the European Comission (DryIR, 623098). MS worked on this paper on a SimulPast contract from the CONSOLIDER-INGENIO 2010 from the MINECO (CSD2010-00034). SB worked on this paper on a Marie Sklodowska-Curie contract from the European Commission. The work of JS was supported in part by the CliSAP Excellence Cluster funded by $D F G$.

\section{LITERATURE CITED}

Adger, W. N. 2003. Social capital, collective action, and adaptation to climate change. Economic Geography 79:387-404. http://dx.doi.org/10.1111/j.1944-8287.2003.tb00220.x

Adger, W. N., J. Barnett, K. Brown, N. Marshall, and K. O'Brien. 2012. Cultural dimensions of climate change impacts and adaptation. Nature Climate Change 3(2):112-117. http://dx.doi. org/10.1038/nclimate1666

Afifi, T., and J. Jäger, editors. 2010. Environment, forced migration and social vulnerability. Springer, Berlin, Heidelberg. http://dx. doi.org/10.1007/978-3-642-12416-7

Agrawal, A. 2003. Indigenous decision-making and hierarchy in migrating pastoralist collectives: the Raika of Western India. Pages 419-447 in M. J. Casimir and A. Rao, editors. Nomadism in South Asia. Oxford University Press, New Delhi, India.

Agrawal, A., K. Kononen, and N. Perrin. 2008. The role of local institutions in adaptation to climate change. Social Development Working Papers. Paper No. 118. June 2009. World Bank, Washington, D.C., USA.

Alberti, G. 2014. Modeling group size and scalar stress by logistic regression from an archaeological perspective. PLOS ONE 9(3): e91510. http://dx.doi.org/10.1371/journal.pone.0091510

Anderson, D. M., C. K. Baulcomb, A. K. Duvivier, and A. K. Gupta. 2010. Indian summer monsoon during the last two millennia. Journal of Quaternary Science 25:911-917. http://dx. doi.org/10.1002/jqs. 1369

Angourakis, A., J. I. Santos, J. M. Galán, and A. L. Balbo. 2015. Food for all: an agent-based model to explore the emergence and implications of cooperation for food storage. Environmental Archaeology: The Journal of Human Palaeoecology 20(4):349-363. http://dx.doi.org/10.1179/1749631414y.0000000041

Armitage, D. R., R. Plummer, F. Berkes, R. I. Arthur, A. T. Charles, I. J. Davidson-Hunt, A. P. Diduk, N. C. Doubleday, D. S. Johnson, M. Marschke, P. McConney, E. W. Pinkerton, and E. K. Wollenberg. 2009. Adaptive co-management for socialecological complexity. Frontiers in Ecology and the Environment 7(2):95-102. http://dx.doi.org/10.1890/070089

Balbo, A. L. 2015. Storage: introduction to the special issue. Environmental Archaeology: The Journal of Human Palaeoecology 20(4):305-313. http://dx.doi.org/10.1179/1749631415Y.0000000021

Balbo, A. L., D. Cabanes, J. J. García-Granero, A. Bonet, P. Ajithprasad, and X. Terradas. 2015. A microarchaeological approach for the study of pits. Environmental Archaeology: The Journal of Human Palaeoecology 20(4):390-405. http://dx.doi. org/10.1179/1749631414y.0000000044

Balbo, A. L., X. Rubio-Campillo, B. Rondelli, M. Ramírez, C. Lancelotti, A. Torrano, M. Salpeteur, N. Lipovetzky, V. ReyesGarcía, C. Montañola, and M. Madella. 2014. Agent-based simulation of Holocene monsoon precipitation patterns and hunter-gatherer population dynamics in semi-arid environments. Journal of Archaeological Method and Theory 32:426-446. http:// dx.doi.org/10.1007/s10816-014-9203-1 
Barceló, M. 1986. La qüestió de l'hidraulisme andalusí. Pages 9-36 in In M. Barceló, editor. Les aigües cercades. Els qanat( $s)$ de l'illa de Mallorca. Institut d'Estudis Baleàrics, Palma de Mallorca, Spain.

Barceló, M. 1989. El diseño de espacios irrigados en al-Andalus: un enunciado de principios generales. Pages 15-40 in L. Cara Barrionuevo, editor. El agua en zonas áridas. Arqueología e Historia. Actas del I Coloquio de Historia y Medio Físico. Instituto de Estudios Almerienses, Almería, Spain.

Barnett, J., and S. O’Neill. 2010. Maladaptation. Global Environmental Change 20(2):211-213. http://dx.doi.org/10.1016/ j.gloenvcha.2009.11.004

Barnosky, A. D., E. A. Hadly, J. Bascompte, E. L. Berlow, J. H. Brown, M. Fortelius, W. M. Getz, J. Harte, A. Hastings, P. A. Marquet, N. D. Martinez, A. Mooers, P. Roopnarine, G. Vermeij, J. W. Williams, R. Gillespie, J. Kitzes, C. Marshall, N. Matzke, D. P. Mindell, E. Revilla, and A. B. Smith. 2012. Approaching a state shift in Earth's biosphere. Nature 486(7401):52-58. http://dx.doi. org/10.1038/nature11018

Barriendos, M. 2005. Climate and culture in Spain, religious responses to extreme climatic events in the Hispanic Kingdoms (16th-19th centuries). Pages 31-86 in W. Behringer, H. Lehmann, and C. Pfister, editors. Cultural consequences of the Little Ice Age. Vandenhoech \& Ruprecht, Göttingen, Germany.

Bates, B. C., Z. W. Kundzewicz, S. Wu, and J. P. Palutikof. 2008. Climate change and water. Technical paper of the Intergovernmental Panel on Climate Change. IPCC Sectetariat, Geneva, Switzerland.

Berkes, F., J. Colding, and C. Folke. 2000. Rediscovery of traditional ecological knowledge as adaptive management. Ecological Applications 10(5):1251-1262. http://dx.doi. org/10.1890/1051-0761(2000)010[1251:roteka]2.0.co;2

Berkes, F., and N. J. Turner. 2006. Knowledge, learning and the evolution of conservation practice for social-ecological system resilience. Human Ecology 34(4):479-494. http://dx.doi. org/10.1007/s10745-006-9008-2

Biagetti, S. 2014. Ethnoarchaeology of the Kel Tadrart Tuareg. Pastoralism and resilience in Central Sahara. Springer, Heidelberg, Germany. http://dx.doi.org/10.1007/978-3-319-08530-2

Christian, W. A. 1982. Local religion in sixteenth century Spain. Princeton University Press, Princeton, New Jersey, USA.

Clift, P. D., and R. A. Plumb. 2008. The Asian monsoon: causes, history, effects, circulation. Cambridge University Press, Cambridge, UK. http://dx.doi.org/10.1017/cbo9780511535833

Colding, J., T. Elmqvist, and P. Olsson. 2002. Living with disturbance: building resilience in social-ecological systems. Pages 163-173 in F. Berkes, J. Colding, and C. Folke, editors. Navigating social-ecological systems: building resilience for complexity and change. Cambridge University Press, Cambridge, UK. http://dx. doi.org/10.1017/cbo9780511541957.011

De Saulieu, G., and A. Testart. 2015. Innovations, food storage and the origins of agriculture. Environmental Archaeology: The Journal of Human Palaeoecology 20(4):314-320. http://dx.doi. org/10.1179/1749631414Y.0000000061
Diamond, J. 2012. The world until yesterday: what can we learn from traditional societies? Viking, New York, New York, USA.

Di Lernia, S., and F. Merighi. 2006. Transitions in the later prehistory of the Libyan Sahara, seen from the Acacus Mountains. Pages 111-122 in D. Mattingly, S. McLaren, E. Savage, Y. al-Fasatwi, and K. Gadgood, editors. The Libyan desert: natural resources and cultural heritage. Society for Libyan Studies, London, UK.

Dong, S., L. Wen, S. Liu, X. Zhang, J. P. Lassoie, S. Yi, X. Li, J. Li, and Y. Li. 2011. Vulnerability of worldwide pastoralism to global changes and interdisciplinary strategies for sustainable pastoralism. Ecology and Society 16(2):10. [online] URL: $\underline{\text { http:// }}$ www.ecologyandsociety.org/vol16/iss $2 / \operatorname{art} 10$

Ertsen, M. W., J. T. Murphy, L. E. Purdue, and T. Zhu. 2013. A journey of a thousand miles begins with one small step-human agency, hydrological processes and time in socio-hydrology. Hydrology and Earth System Sciences Discussions 18:1369-1382. http://dx.doi.org/10.5194/hess-18-1369-2014

Fereres, E., and M. A. Soriano. 2007. Deficit irrigation for reducing agricultural water use. Journal of Experimental Botany 58(2):147-159. http://dx.doi.org/10.1093/jxb/erl165

Flores Cala, J. 2005. Historia y documentos de los traslados de la virgen del Rocío a la Villa de Almonte 1607-2005. Cuadernos de Almonte, Huelva, Spain.

Folke, C., J. Colding, and F. Berkes. 2002. Synthesis: building resilience and adaptive capacity in social-ecological systems. Pages 352-387 in F. Berkes, J. Colding, and C. Folke, editors. Navigating social-ecological systems: building resilience for complexity and change. Cambridge University Press, Cambridge, UK. http://dx.doi.org/10.1017/cbo9780511541957.020

Food and Agriculture Organization of the United Nations (FAO). 2001. Pastoralism in the new millenium. FAO, Rome, Italy.

Fort, J., T. Pujol, and M. Vander Linden. 2012. Modelling the Neolithic transition in the Near East and Europe. American Antiquity 77(2):203-219. http://dx.doi.org/10.7183/0002-7316.77.2.203

Galvin, K. A. 2009. Transitions: pastoralists living with change. Annual Review of Anthropology 38(1):185-198. http://dx.doi. org/10.1146/annurev-anthro-091908-164442

García-Barrón , L., M. Aguilar, and A. Sousa. 2011. Evolution of annual rainfall irregularity in the southwest of the Iberian Peninsula. Theoretical and Applied Climatology 103(1):13-26. http://dx.doi.org/10.1007/s00704-010-0280-0

Giansante, C., M. Aguilar, L. Babiano, A. Garrido, A. Gómez, E. Iglesias, W. Lise, L. Moral, and B. Pedregal. 2003. Institutional adaptation to changing risk of water scarcity in the lower Guadalquivir Basin. Natural Resources Journal 42:521-563.

Gifford-Gonzalez, D., and O. Hanotte. 2011. Domesticating animals in Africa: implications of genetic and archaeological findings. Journal of World Prehistory 24(1):1-23. http://dx.doi. org/10.1007/s10963-010-9042-2

Glick, T. F. 1990. El sentido arqueológico de las instituciones hidráulicas. Regadío bereber y regadío español. Pages 154-171 in 
Aragón vive su historia. II Jornadas de Cultura Islámica. Instituto Occidental de Cultura Islámica, Madrid, Spain.

Gómez-Baggethun, E., E. Corbera, and V. Reyes-García, V. $2013 b$. Traditional ecological knowledge and global environmental change: research findings and policy implications. Ecology and Society 18(4):72. http://dx.doi.org/10.5751/ES-06288-180472

Gómez-Baggethun, E., E. Kelemen, B. Martín, I. Palomo, and C. Montes. 2013a. Scale misfit in ecosystem service governance as a source of environmental conflict. Society \& Natural Resources 26:1202-1216. http://dx.doi.org/10.1080/08941920.2013.820817

Gómez-Baggethun, E., S. Mingorría, V. Reyes-García, L. Calvet, and C. Montes. 2010. Traditional ecological knowledge trends in the transition to a market economy: empirical study in Doñana natural areas. Conservation Biology 24:721-729. http://dx.doi. org/10.1111/j.1523-1739.2009.01401.x

Gómez-Baggethun, E., and V. Reyes-García. 2013. Reinterpreting change in traditional ecological knowledge. Human Ecology 41:643-647. http://dx.doi.org/10.1007/s10745-013-9577-9

Gómez-Baggethun, E., V. Reyes-García, P. Olsson, and C. Montes. 2012. Traditional ecological knowledge and community resilience to environmental extremes: a case study in Doñana, SW Spain. Global Environmental Change 22(3):640-650. http://dx.doi. org/10.1016/j.gloenvcha.2012.02.005

Guichard, P. 1976. Al-Andalus: estructura antropológica de una sociedad islámica en occidente. Editorial Barral, Barcelona, Spain.

Guijt, I., and J. Thompson. 1994. Landscapes and livelihoods: environmental and socioeconomic dimensions of small-scale irrigation. Land Use Policy 11(4):294-308. http://dx.doi. org/10.1016/0264-8377(94)90055-8

Guinot, E., and F. Esquilache. 2012. La reorganización del paisaje agrario en la huerta de Valencia después de la conquista cristiana. El sistema hidráulico y el parcelario de Montcada y Benifaraig en el siglo XIII. Debates de Arqueología Medieval 2:229-276.

Haque, C. E., and D. Etkin. 2007. People and community as constituent parts of hazards: the significance of societal dimensions in hazards analysis. Natural Hazards 41(2):271-282. http://dx.doi.org/10.1007/s11069-006-9035-8

Hardin, G. 1968. The tragedy of the commons. Science 162 (3859):1243-1248.

Hill, R., G. A. Dyer, L.-M. Lozada-Ellison, A. Gimona, J. MartinOrtega, J. Munoz-Rojas, and I. J. Gordon. 2015. A socialecological systems analysis of impediments to delivery of the Aichi 2020 Targets and potentially more effective pathways to the conservation of biodiversity. Global Environmental Change 34:22-34. http://dx.doi.org/10.1016/j.gloenvcha.2015.04.005

Hoffman, S. M., and A. Oliver-Smith, editors. 2002. Catastrophe and culture. The anthropology of disaster. School of Advanced Research Press, Santa Fe, New Mexico, USA.

Holling, C. S., and G. K. Meffe. 1996. Command and control and the pathology of natural resource management. Conservation Biology 10(2):328-337. http://dx.doi.org/10.1046/ j.1523-1739.1996.10020328.x
Hussein, K. 1998. Conflicts between farmers and herders in the semi-arid Sahel and East Africa: a review. International Institute for Environment and Development, London, UK.

Iniesta-Arandia, I., D. García del Amo, A. P. García-Nieto, C. Piñeiro, C. Montes, and B. Martín-López. 2015. Factors influencing local ecological knowledge maintenance in Mediterranean watersheds: insights for environmental policies. AMBIO 44(4):285-296 http://dx.doi.org/10.1007/s13280-014-0556-1

Intergovernmental Panel on Climate Change (IPCC). 2012. Managing the risks of extreme events and disasters to advance climate change adaptation. Special Report of Working Groups I and II of the Intergovernmental Panel on Climate Change. C. B. Field, V. Barros, T. F. Stocker, D. Qin, D. J. Dokken, K. L. Ebi, M.D. Mastrandrea, K. J. Mach, G.-K. Plattner, S. K. Allen, M. Tignor, and P. M. Midgley, editors. Cambridge University Press, Cambridge, UK.

Johnson, G. A. 1982. Organizational structure and scalar stress. Pages 389-421 in C. Renfrew, M. J. Rowlands, and B. A. Segraves, editors. Theory and explanation in archaeology. The Southampton Conference. Academic Press, New York, New York, USA.

Kavoori, P. S. 1996. Pastoralism in expansion: the transhuming sheep herders of western Rajasthan. Dissertation. Institute of Social Studies, The Hague, Netherlands.

Kirchner, H. 2009. Original design, tribal management and modifications in medieval hydraulic systems in the Balearic Islands (Spain). World Archaeology 41(1):151-168. http://dx.doi. org/10.1080/00438240802668222

Kramer, K. L. 2005. Maya children. Helpers at the farm. Harvard University Press, Boston, Massachusetts, USA.

Kristofferson, A. H. A., and F. Berkes. 2005. Adaptive comanagement of Arctic char in Nunavut Territory. Pages 249-268 in F. Berkes, R. Huebert, H. Fast, M. Manseau, and A. Diduck, editors. Breaking ice: renewable resource and ocean management in the Canadian North. University of Calgary Press, Calgary, Alberta, Canada.

Kuijt, I. 2015. The Neolithic refrigerator on a Friday night: how many people are coming to dinner, and just what should I do with the slimy veggies in the back of the fridge. Environmental Archaeology: The Journal of Human Palaeoecology 20(4):321-336. http://dx.doi.org/10.1179/1749631415y.0000000003

Kuijt, I., and B. Finlayson. 2009. Evidence for food storage and predomestication granaries 11,000 years ago in the Jordan Valley. Proceedings of the National Academy of Sciences of the United States of America 106(27):10966-10970. http://dx.doi.org/10.1073/ pnas.0812764106

López-Taillefert, M.A. 1998. Las Venidas de Ntra. Sra. del Rocío a la villa de Almonte (1607-1998). Hermandad Matriz de Almonte, Huelva, Spain.

Maas, A., and R. L. Anderson. 1978....And the desert shall rejoice: conflict, growth and justice in arid environments. MIT Press, Cambridge, Massachusetts, USA.

Mabry, J. B., editor. 1996a. Canals and communities. Small-scale irrigation systems. University of Arizona Press, Tucson, Arizona, USA. 
Mabry, J. B. 1996b. The ethnology of local irrigation. Pages 3-32 in J. B. Mabry, editor. Canals and communities. Small-scale irrigation systems. University of Arizona Press, Tucson, Arizona, USA.

Marshall, F. 2000. The origins and spread of domestic animals in East Africa. Pages 191-221 in R. Blench and K. C. McDonald, editors. The origins and development of African livestock: archaeology, genetics, linguistics and ethnography. UCL Press, London, UK.

Martínez-Fernández, J., M. A. Esteve-Selma, I. Baños-González, F. Carreño, and A. Moreno. 2013. Sustainability of Mediterranean irrigated agro-landscapes. Ecological Modelling 248:1-19. http://dx.doi.org/10.1016/j.ecolmodel.2012.09.018

Mattingly, D. J., and M. Sterry. 2013. The first towns in the central Sahara. Antiquity 87(336):503-518. http://dx.doi.org/10.1017/ $\underline{\mathrm{s} 0003598 \times 00049097}$

McCarthy, N., B. Swallow, M. Kirk, and P. Hazell, editors. 2000. Property rights, risk, and livestock development in Africa. International Food Policy Research Institute, Washington, D.C., USA, and International Livestock Research Institute, Nairobi, Kenya.

McGlade, J. 2014. Simulation as narrative: contingency, dialogics, and the modeling conundrum. Journal of Archaeological Method and Theory 21(2):288-305. http://dx.doi.org/10.1007/s10816-014-9201-3

McIntosh, R. J., J. A. Tainter, and S. K. McIntosh. 2000. Climate, history and human action. Pages 1-43 in R. J. McIntosh, J. A. Tainter, and S. K. McIntosh, editors. The way the wind blows: climate, history, and human action. Columbia University Press, New York, New York, USA.

Meier, R. L. 1972. Communications stress. Annual Review of Ecology and Systematics 3:289-314. http://dx.doi.org/10.1146/ annurev.es.03.110172.001445

Mori, L. 2013. Life and death at Fewet. Pages 375-387 in L. Mori, editor. Life and death of a rural village in Garamantian times. Edizioni All'Insegna del Giglio, Firenze, Italy.

Mumford, L. 1934. Technics and civilization. Harcourt, Brace \& Company, New York, New York, USA.

Ngaruiya, W. G., J. Scheffran, and L. Yang. 2015. Social networks in water governance and climate adaptation in Kenya. Pages 151-167 in W. Leal Filho and V. Sümer, editors. Sustainable water use and management. Springer, Berlin, Germany. http://dx.doi. org/10.1007/978-3-319-12394-3 8

Nori, M., and J. Davies. 2007. Change of wind or wind of change? Climate change, adaptation and pastoralism. World Initiative for Sustainable Pastoralism. International Union for Conservation of Nature, Nairobi, Kenya.

Nori, M., M. Taylor, and A. Sensi. 2008. Browsing on fences: pastoral land rights, livelihoods and adaptation to climate change. International Institute for Environment and Development, London, UK.

O'Brien, M. J., and R. A. Bentley. 2015. The role of food storage in human niche construction: an example from Neolithic Europe. Environmental Archaeology: The Journal of Human Palaeoecology 20(4):364-378. http://dx.doi.org/10.1179/1749631414y.0000000053
Ojeda, J. F. 1987. Organización del territorio en Doñana y su entorno próximo. (Almonte). Siglos XVIII-XX. Ministerio de Agricultura, Instituto Nacional para la Conservación de la Naturaleza, Madrid, Spain.

Oliver-Smith, A. 1999. What is a disaster?: anthropological perspectives on a persistent question. Pages 18-34 in A. OliverSmith and S. Hoffmann, editors. The angry earth: disaster in anthropological perspective. Routledge, New York, New York, USA.

Ostrom, E. 1990. Governing the commons: the evolution of institutions for collective action. Cambridge University Press, Cambridge, UK. http://dx.doi.org/10.1017/CBO9780511807763

Oteros-Rozas, E., R. Ontillera-Sánchez, P. Sanosa, E. GómezBaggethun, V. Reyes-García, and J. A. González. 2013. Traditional ecological knowledge among transhumant pastoralists in Mediterranean Spain. Ecology and Society 18(3):33. http://dx. doi.org/10.5751/ES-05597-180333

Patel, A. K. 2009. Occupational histories, settlements, and subsistence in Western India: what bones and genes can tell us about the origins and spread of pastoralism. Anthropozoologica 44:173-188. http://dx.doi.org/10.5252/az2009n1a8

Pelling, M., and C. High. 2005. Understanding adaptation: what can social capital offer assessments of adaptive capacity? Global Environmental Change 15:308-319. http://dx.doi.org/10.1016/j. gloenvcha.2005.02.001

Pérez, I., M. A. Janssen, A. Tenza, A. Giménez, A. Pedreño, and M. Giménez. 2011. Resource intruders and robustness of socialecological systems: an irrigation system of Southeast Spain, a case study. International Journal of the Commons 5(2):410-432. http://dx.doi.org/10.18352/ijc. 278

Piguet, É., A. Pécoud, and P. De Guchteneire. 2011. Migration and climate change. Political Studies Review. Volume 11. Cambridge University Press, Cambridge, UK.

Puy, A., and A. L. Balbo. 2013. The genesis of irrigated terraces in al-Andalus. A geoarchaeological perspective on intensive agriculture in semi-arid environments (Ricote, Murcia, Spain). Journal of Arid Environments 89:45-56. http://dx.doi.org/10.1016/ j.jaridenv.2012.10.008

Puy, A., A. L. Balbo, and O. Bubenzer. 2016. Radiocarbon dating of agrarian terraces by means of buried soils. Radiocarbon, available on CJO2016. http://dx.doi.org/10.1017/RDC.2015.21

Pyhälä, A., Á. Fernández-Llamazares, H. Lehvävirta, A. Byg, I. Ruiz-Mallén, M. Salpeteur, and T. F. Thornton. 2016. Global environmental change: local perceptions, understandings, and explanations. Ecology and Society 21(3) in press.

Retamero, F. 1998. Un conjunto de reglas sabias y ordenadas. La disciplina agraria del sultán. Pages 61-66 in C. Laliena and J. Utrilla, editors. De Toledo a Huesca. Sociedades medievales en transición a finales del siglo XI (1080-1100). Institución Fernando el Católico, Zaragoza, Spain.

Reyes-García, V., M. Guèze, A. C. Luz, J. Paneque-Gálvez, M. J. Macía, M. Orta-Martínez, J. Pino, and X. Rubio-Campillo. 2013. Evidence of traditional knowledge loss among a contemporary indigenous society. Evolution \& Human Behavior 34(4):249-257. http://dx.doi.org/10.1016/i.evolhumbehav.2013.03.002 
Robinson, L. W., and F. Berkes. 2010. Applying resilience thinking to questions of policy for pastoralist systems: lessons from the Gabra of Northern Kenya. Human Ecology 38(3):335-350. http:// dx.doi.org/10.1007/s10745-010-9327-1

Rockström, J., W. Steffen, K. Noone, Å. Persson, F. S. Chapin, III, E. Lambin, T. M. Lenton, M. Scheffer, C. Folke, H. Schellnhuber, B. Nykvist, C. A. De Wit, T. Hughes, S. van der Leeuw, H. Rodhe, S. Sörlin, P. K. Snyder, R. Costanza, U. Svedin, M. Falkenmark, L. Karlberg, R. W. Corell, V. J. Fabry, J. Hansen, B. Walker, D. Liverman, K. Richardson, P. Crutzen, and J. Foley. 2009. Planetary boundaries: exploring the safe operating space for humanity. Ecology and Society 14(2):32. [online] URL: http:// www.ecologyandsociety.org/vol14/iss2/art32/ http://dx.doi.org/10.1111/ j.1540-5842.2010.01142.x

Rodríguez Díaz, J. A., E. K. Weatherhead, J. W. Knox, and E. Camacho. 2007. Climate change impacts on irrigation water requirements in the Guadalquivir river basin in Spain. Regional Environmental Change 7(3):149-159. http://dx.doi.org/10.1007/ s10113-007-0035-3

Romero Macías, E., M. A. Gonzalez Martínez, and D. L. Orihuela Calvo. 1996. Evolución espacio-temporal de la salinidad de acuíferos en regiones semiáridas [Spatio-temporal evolution of water table salinity in semiarid regions]. Preparque norte del Parque Nacional de Doñana. Huelva-España IV simposio sobre el agua en Andalucía. Volumen II. Madrid, Spain.

Salpeteur, M., M. Madella, H. Patel, and V. Reyes-García. Adaptation, access to resources and mobility: from contemporary pastoral systems to ancient societies. Nomadic Peoples, in press.

Salpeteur, M., H. Patel, A. L. Balbo, X. Rubio-Campillo, M. Madella, P. Ajithprasad, and V. Reyes-García. 2015. When knowledge follows blood. Kin groups and the distribution of traditional knowledge in a community of seminomadic pastoralists, Gujarat (India). Current Anthropology 56 (3):471-483. http://dx.doi.org/10.1086/681006

Sauri, D., V. Domingo, and A. Romero. 2003. Trust and community building in the Donana (Spain) toxic spill disaster. Journal of Risk Research 6:145-162. http://dx.doi. org/10.1080/1366987032000078910

Scheffran, J. 2011. Security risks of climate change: vulnerabilities, threats, conflicts and strategies. Pages 735-756 in H. G. Brauch, Ú. Oswald Spring, C. Mesjasz, J. Grin, P. KameriMbote, B. Chourou, P. Dunay, and J. Birkmann, editors. Coping with global environmental change, disasters and security. Springer, Berlin, Germany. http://dx.doi.org/10.1007/978-3-642-17776-7_42

Scheffran, J., M. Brzoska, J. Kominek, P. M. Link, and J. Schilling. 2012a. Climate change and violent conflict. Science 336 (6083):869-871. http://dx.doi.org/10.1126/science.1221339

Scheffran, J., E. Marmer, and P. Sow. 2012b. Migration as a contribution to resilience and innovation in climate adaptation: social networks and co-development in Northwest Africa. Applied Geography 33:119-127.

Sitjes, E. 2006. Inventario y tipología de sistemas hidráulicos en al-Andalus. Arqueología Espacial 26:263-291.
Smith, E. A., and M. Wishnie. 2000. Conservation and subsistence in small-scale societies. Annual Review of Anthropology 29 (1):493-524. http://dx.doi.org/10.1146/annurev.anthro.29.1.493

Sousa, A., and P. García-Murillo. 2003. Changes in the wetlands of Andalusia (Doñana Natural Park, SW Spain) at the end of the Little Ice Age. Climatic Change 58(1):193-217.

Sow, P., E. Marmer, and J. Scheffran. 2015. Between the heat and the hardships. Climate change and mixed migration flows in Morocco. Migration and Development 1-21.

Stafford Smith, D. M., N. Abel, B. Walker, and F. Stuart Chapin, III. 2009. Drylands. Coping with uncertainty, thresholds and changes in state. Pages 171-196 in F. S. Chapin, III, G. P. Kofinas, and C. Folke, editors. Principles of ecosystem stewardship. Resilience-based natural resource management in a changing world. Springer, New York, New York, USA.

Thornton, T. F., and N. Manasfi. 2010. Adaptation-genuine and spurious: demystifying adaptation processes in relation to climate change. Environment and Society: Advances in Research 1 (1):132-155. http://dx.doi.org/10.3167/ares.2010.010107

Torró, J. 2007. Terrasses irrigades a les muntanyes valencianes: les transformacions de la colonització cristiana. Pages 81-145 in J. Bolós, editor. Estudiar i gestionar el paisatge històric medieval. IV. Territori $i$ societat a l'Edat Mitjana. Universitat de Lleida, Lleida, Spain.

Torry, W. I., W. A. Anderson, D. Bain, H. J. Otway, F. D. Souza, P. O. Keefe, J. P. Osterling, B. A. Turner, D. Turton, and M. Watts. 1979. Anthropological studies in hazardous environments: past trends and new horizons. Current Anthropology 20(3):517-540.

Watson, A. M. 1983. Agricultural innovation in the Early Islamic World. Cambridge University Press, Cambridge, UK.

Wildcat, D.R. 2013. Introduction: climate change and indigenous peoples of the USA. Climatic Change 120:509-515. http://dx.doi. org/10.1007/s10584-013-0849-6

Wilson, A. 2012. Saharan trade in the Roman period: short-, medium- and long-distance trade networks. Azania 47 (4):409-449. http://dx.doi.org/10.1080/0067270x.2012.727614

Winterhalder, B., C. Puleston, and C. Ross. 2015. Production risk, inter-annual food storage by households and population-level consequences in seasonal prehistoric agrarian societies. Environmental Archaeology. The Journal of Human Palaeoecology 20(4):337-348. http://dx.doi.org/10.1179/1749631415y.0000000025 